\title{
The Ritualized Bodies of Cybele's Galli and the Methodological Problem of the Plurality of Explanations
}

\author{
Quae sunt sacrilegia, si illa sunt sacra? \\ aut quae inquinatio, si illa lavatio? ${ }^{1}$ \\ (Aug. De Civ. Dei II.4).
}

In our studies in the history of religions we are sometimes confronted by events and phenomena that seem to crave for an explanation, and, if the phenomenon does not conform with our world-view, ${ }^{2}$ or the prima facie interpretation does not seem plausible, the more urgently we feel the need for some sort of understanding. This is, I think, especially the case with what we, from our horizon of understanding, deem to be abnormal human behaviour.

The Christian polemicist Prudentius, 348 - c. 410 , writes about the Dendrophoria festival of Cybele and the transition ritual of her cultic servants, the Galli:

There are rites in which you mutilate yourself and maim your bodies to make an offering of the pain. A worshipper possessed thrusts the knife into his arms and cuts them to propitiate the Mother goddess. Frenzy and wild whirling are thought to be the rule of her mysteries. The hand that spares the cutting is held to be undutiful, and it is the barbarity of the wound that earns heaven. Another makes the sacrifice of his genitals; appeasing the goddess by mutilating his loins, he unmans himself and offers her a shameful gift; the source of the man's seed is torn away to give her food and increase through the flow of blood. Both sexes are displeasing to her holiness, so she keeps a middle gender between the two, ceasing to be a man without becoming a woman. (Prudentius, Perist. 1059-1073)

\footnotetext{
1 "What are profane, if these are sacred rites? Or what is pollution, if these is ablution?"

2 Those fundamental cognitive orientations by which men order their lives (Spiro 1987: 18).
} 
The explanandum in this article is the self-castration of Cybele's Galli. ${ }^{3}$ The explanans is the various theories that have been put forward to elucidate this phenomenon. I will begin by sketching out the complicated religio-historical scene for this ritual, then introduce the plurality of theories concerning Galli's ritual self-castration, so that the intellectual dilemma of evaluation and preference is obvious; which one of the theories is decisive? Are they necessary or sufficient? Do they compete or cooperate?

The aim of this article is also to make a critical methodological evaluation of the use of psychological determinants in religio-historical studies of the self-castration of the Galli in the cult of Cybele and Attis. My study will, accordingly, deal with the epistemological status of historically used psychological methods and their entanglement with the complex question of historical explanation.

\section{The Religio-Historical Scene: the Drama and the Many Scripts}

It is my opinion that we should study the ritual behaviour of the Galli from a dramaturgical standpoint, that is by using perspectives which emphasize the sociological functions of their religious performance of culturally prescribed roles, a reconstruction of the script, i.e. those mythological narratives that are used by the adherents in their religiously intrinsic understanding etc. (Harré and Secord 1972: 205-225; Spiro 1987: 109144).

\subsection{The Narration of Lucianus in De Dea Syria}

Lucianus ${ }^{4}$ delineates in De Dea Syria a vivid description of the cultic scene at Atargatis' sanctuary in the Syrian city Hierapolis:

\footnotetext{
3 The modern study of the Galli was inaugurated in the history of religions by Hugo Hepding (1903) and H. Graillot (1912), both of them including collections of literary sources and relevant epigraphic material, then available. For an overview of recent studies, see Vermaseren 1966, Vermaseren 1977, Sanders 1972; Thomas 1984. See also Widengren 1953 concerning ritual emasculation of enemies during war in the ancient Middle East.

4 The authenticity of the author, Lucian of Samosata?, is under dispute, see Bilde 1990: 162-166. "Lucian" is used in the article without the intention of making any commitment in this complicated question.
} 
On appointed days, the crowd assembles at the sanctuary while many Galli and the holy men whom I have mentioned perform the rites. They cut their arms and beat one another on the back. Many stand about them playing flutes, while many others beat drums. Still others sing inspired and sacred songs. This ceremony takes place outside the temple and none of those who perform it enters the temple. On these days too, men become Galli. For while the rest are playing flutes and performing the rites, frenzy comes upon many, and many who have come simply to watch subsequently perform this act. I will describe what they do. The you th for whom these things lie in store throws off his clothes, rushes to the center with a great shout and takes up a sword, which, I believe has stood there for this purpose for many years. He grabs it and immediately castrates himself. Then he rushes through the city holding in his hands the parts he has cut off. He takes female clothing and women's adornment from whatever house he throws these parts into. This is what they do at the Castration. (Lucianus, De Dea Syria 50-51)

Lucianus gives two aitiological traditions to explain this religious ritual. The first one, which we can call the Attis' tradition, relates how the sanctuary at Hierapolis is the creation of the Lydian Attis, who taught the rites concerning Rhea to the Phrygians, Lydians and inhabitants of Samothrace and was castrated by her. Afterwards he took on a feminine form, including female clothing and went out to every land to perform the rites and to tell about his sufferings. In due time he came to Syria and laid the foundation of the sanctuary (Lucianus, De Dea Syria 15). Lucianus then compares the similarities between the Hieropolitanian goddess Atargatis - whom he constantly calls Hera as an interpretatio graeca - and the way the Lydians depict Rhea, i.e. Magna Mater, and he concludes pertaining to this tradition of Attis: "The wise man also said about the Galli who are in the temple, that Galli never castrate themselves for Hera,

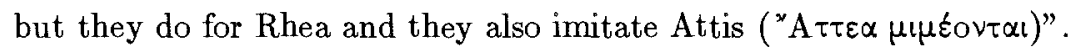

The second tradition (Lucianus, De Dea Syria 19-27), which we can call the Combabus' tradition, narrates how the Assyrian king assigned one of his favorite heroes, the handsome Combabus, to escort his royal consort Stratonice to Hierapolis, because she had been told by Hera in a dream to build a temple there. To avoid compromising himself with the beautiful queen he castrated himself before the departure to Hierapolis and entrusted his virilia to the Assyrian king in a sealed vessel. Stratonice fell in love with Combabus and in spite of his telling her of the great sacrifice she passed all the time with him. The rumour reached the king and he summoned Combabus and condemned him to death. But by breaking the seal on the vessel and by showing the virilia to the king he was declared innocent and bestowed with great honours. The King said 
to him: "You will also have access to us without any to announce you, nor will anyone bar you from our sight, not even if $I$ am in bed with my wife." Lucianus then relates that Combabus' dearest friends emasculated themselves as a consolation for his sufferings and followed his life style, or that Hera, out of love for him, imparted the idea of castration on others so Combabus might not grieve alone. The wearing of female dress is explained by the fact that during a festival a foreign woman had fallen in love with the emasculated Combabus, then still wearing men's clothing, but to avoid this in the future he changed to female clothing.

E. Benveniste has suggested that this tradition about Combabus is a widespread legendary story, with roots in the Persian court romance, which Lucianus has used in order to explain a local rite (Benveniste 193839: 249-258).

Despite the fact that Lucianus declares that the reason for the selfcastration of the Galli is the story of Combabus, which according to him is much more believable than the Attis' tradition, I would prefer to see this legendary story as a secondary elaboration, and as Benveniste has pointed out with a genesis in the Persian court tradition. The Combabus' tradition could be an originally aitiological explanation of the Assyrian system of eunuchs as chamberlains - notice that Combabus always should have free passage to the king - and as generals, governors (see Gray 1912; Browe 1936), which later on have been adopted to fit in with the cult at Hierapolis. We can also note that the explanation of the female clothing in the Combabus' tradition as a mean of averting the interest of women is contradicted by Lucianus himself when he narrates that the love between Stratonice and Combabus still exists in Hierapolis. "Women desire the Galli and the Galli go mad for a woman. Yet, no one is jealous, for they consider the matter quite holy" (Lucianus, De Dea Syria 22).

It seems to me that many mythological, literary and "folk-loristic" traditions are coming to a sort of crossroad in the De Dea Syria, and by incidents lucidly describing the situation of the hellenistic Religionsmengerei. We have a description of the ritual of selfemasculation that in some way seems to be connected with the Phrygian myths of Attis. We shall now therefore turn to this mythological legacy with its focal point in Pessinus in Phrygia - the Metropolis for the cult of Magna Mater. 


\subsection{The Phrygian Mythographical Tradition According to Pausanias and Arnobius}

The myth accompanying the self-castration of Cybele's Galli is in this case of course the tragic story of Attis, in the Phrygian versions. ${ }^{5}$ Pausanias (VII, 17, 10-12) reports that a hermaphroditic monster, Agdistis, was born when Zeus fecundated the soil in his sleep. The Gods feared him and cut off the daemonic creature's male organs, out of which there sprung up an almond tree with ripe fruits. The daughter of the river Sangarios put some of the fruits in a fold of her dress and so became pregnant with Attis. Grown up, Attis was celebrating his marriage with the daughter of the king of Pessinus, when Agdistis, who had fallen in love with him, entered during the wedding song. At the sight of Agdistis Attis went mad and chopped off his private parts, and the king did the same. Agdistis regretted what he had done and made Zeus grant that Attis' body should never corrupt or wither in the least degree.

The Phrygian version of the myth is found in a more elaborated form in the Christian polemicist Arnobius' work Adversus nationes (V, 5-7). In this mythographical compilation - here not commenting on other additions $^{6}$ - Attis mutilated himself under a pine tree and bled to death. He was loved both by Acdestis ${ }^{7}$, who infused fury and madness, and by the Mother of the Gods. Violets sprung forth from his blood and entwined the tree. The mother of the Gods took the pine to her cave and there Acdestis also joined in the lamentations. Arnobius continues:

Jupiter refuses Acdestis' request that Attis might come back to life. But what is possible by concession of fate, this he grants without objecting: that his body should not decay, that his hair should ever grow, that the very smallest of his fingers should live and alone react by continued motion. Satisfied with these favors, Acdestis, it is said, consecrated the body in Pessinus, and honoured it with annual rites and with a sacred ministry. ${ }^{8}$

5 Concerning the Lydian tradition which relates how Attis was mutilated by a wild boar and bled to death (Pausanias VII, 17, $5 \mathrm{ff}$.) or accidently pierced by Adrastus' lance while hunting wild boar (Herodotos I, 34-35), see Hepding 1903: 98102; Vermaseren 1966: 2-3; Vermaseren 1977: 88-92.

'For a detailed comparison between Pausanias' and Arnobius' versions of the Phrygian myth, see Hepding 1903: 103-110.

7 The variant orthography found in Arnobius of Sicca 1949: 569 note 29.

8 See Podeman Sørensen 1989: 23-29 for an analysis of the binary oppositions in the Arnobian version of the myth. 


\section{The Interpretations of Galli's Self-castration}

The implicit question which has haunted us since we first confronted the phenomenon of Galli's self-castration is explicitly put by Britt-Mari Näsström (1989: 70):

Why did Attis and his priests castrate themselves? Why did they commit this

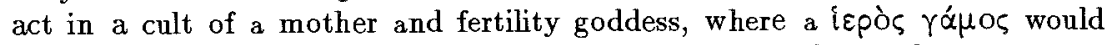
illustrate the appropriate symbol of prosperity and reproduction?

As early as 1923 Arhur Darby Nock collected a list of answers and added his own proposal 'on top of them'. Walter Burkert did likewise in 1979 and recently Britt-Mari Näsström. In the following I shall outline the various interpretations given and try to evaluate and categorize them. But I will begin by studying the epistemological and pragmatical status of the question in focus.

The question "Why did Attis and his priests ${ }^{9}$ castrate themselves?" is, according to my view, too open-ended and unclear, and it belongs to the context of discovery, not to the analytical questioning of the material. If we consult David Hackett Fischer's inventory of historian's fallacies, we clearly see that it could be called a case of "the fallacy of many questions". Hackett Fischer's first criterion is that a common form of error is the framing of a question in such a way that two or more questions are asked at once and a single answer is required (Hackett Fischer 1970: 8). We cannot, to my mind, equate the reasons for Attis' own castration on the mythological level, with other various reasons that could have motivated the Galli, without mixing together mythological thinking and in principle describable historical personal motives that, in their turn, could be based on psychological, sociological and other factors.

Another criterion concerning the "the fallacy of many questions" is framing a question which makes a false presumption (Hackett Fischer 1970: 8), a criterion that might be applicable to Näsström' hypothesis about the suitability of a hieros gamos instead of the actual castration. We can only begin by looking at the actual situation in the mythological evidence; we have the love and jealousy of Agdistis towards Attis

\footnotetext{
9 According to Garth Thomas the Galli were not priests, because of the mode of initiation, but they could be named by the vague term "clergy" and he continues by remarking that the confusion is not new, Pliny (N.H. 35, 165) calls them sacerdotes. A more suitable phenomenological category could be "cultic personnel", a vague enough term that does not have Christian connotations.
} 
followed by Attis' furious self-castration. We cannot confront this with a hypothetical and imagined hieros gamos.

Hackett Fischer is furthermore in general very skeptical about "why" questions, because these tend to become metaphysical questions, "why was the war inevitable?", and they are also imprecise, for the adverb "why" is difficult to define. It can refer to a cause, a motive, a reason, a description, a process and many other things. Hackett Fischer even goes so far as to propose that this "favorite adverb of historians should be consigned to the semantical rubbish heap" (Hackett Fischer 1970: 14-15). I cannot accept this proposition, because we are using "why" questions not in a coherent way in the historiographical process, be it in the history of religions or political history, but in a hermeneutically understandable way if we try to be more precise about what kinds of "why" questions we are searching to answer. It is my opinion that by categorizing the hypotheses that have been put forward, we will be able to see what sort of "why" question they have, in an implicit way, answered. This will in turn make it possible to make a coherent, overall evaluation of the various solutions that have been attempted.

\subsection{Frazer's Instrumental Interpretations of Self-castration as a Means to Regenerate the Vegetational Cycle}

Frazer's disputed interpretative paradigm with dying and rising vegetation deities may, concerning Attis, be recapitulated in the following way. Attis' seasonal and cyclical being is manifested in the annual Dendrophoria with his birth and growth, death and fading in analogy to the vegetation cycle.

According to Frazer's view the Galli castrated themselves in order to fecundate Mother Earth, so that Attis and the vegetation could be reborn. Frazer's interpretation is based on two premises. The first is that the Galli personified the Goddess' mystical lover Attis, what could be called imitatio Attidis, so that the Goddess, through them, could receive lifegiving energy and transmit it to the world. The second is the custom of deposing the castrated organs in the earth or in subterranean chambers sacred to Cybele. From this Frazer conjectures that they may have had an instrumental purpose in recalling Attis to life and giving help to the seasonal regeneration and growth (Frazer 1914: 263-280).

This synthesizing interpretative paradigm of dying and rising vegetation deities, planted by Wilhelm Mannhardt and tenderly cultivated by Frazer has been severely pruned by recent scholarship (see e.g. Gurney 1962). Concerning Attis this has especially been the case with his resurrection, 
i.e. the celebration at Hilaria. The textual evidence is here, according to Frazer, Firmicus Maternus (De errore 22) which, however, Jørgen Podeman Sørensen has convincingly shown to be related to Osiris and not to Attis (Podeman Sørensen 1989: 73-86). Against this negative evidence can be put the term Hilaria, allegorical readings from late Antiquity and Damascius' description in his biography of his teacher Isidorus (Frazer 1914: 272-274).

I think it could be wise in this context to keep apart three questions. Firstly the relevance of Frazer's interpretative paradigm in toto, that is including Adonis, Attis and Osiris as dying and rising vegetation deities. This grandiose network of branches can now be regarded as discarded into the fire. Secondly Attis is interpreted in late antique sources as the harvested corn - the castration; the collecting of the seed in underground chambers - the death of Attis; when the sown seed sprouts in the spring - The regeneration of Attis, "vitam rursus" Firmicus Maternus (3.2). Thirdly Frazer's interpretatio christiana of Attis cyclical and vegetative regeneration, which makes it analogous to Christ's bodily resurrection.

The difference between these two "resurrections" can be shown if we take a look at the ending of the Arnobian version of the Phrygian myth (Adversus nationes V. 7, 123 ff. in Hepding 1903: 40-41). Attis' post mortem being, with a continuing growth of the hair and a little finger ever in motion, seems to denotate a vegetative metaphoric context. Hair, "coma", could be associated with grass and sprigs. Finger, "digitus", can denotate a little sprig. We should place these conjectures in the context of one of the names of the Galli - Digiti Idaei. These "fingers of Mount Ida" are also found in the Greek form Idaei dactyli in Arnobius (Adversus nationes III.41).

In the symbolic universe of Arnobius we find a complicated web of vegetative imaginations. Attis, the harvested corn and the evergreen pine, is associated in his latency of death, that is in his surviving in death, with growing and sprouting vegetation. This is manifested by the smallest bodily sign, a constantly moving little finger, maybe alluding to the membrum virile and in that case particularly important in the castration context.

The ritual of the Galli's self-castration is explained by its belonging to the paradigm of dying and rising vegetation deities according to Frazer. This is an explanation by definition. The self-emasculation is viewed as "instrumental in recalling Attis to life and hastening the general resurrection of nature" (Frazer 1914: 269). It also enables a person to become a Gallus (Frazer 1914: 265). So we have two functional explanations, the 
earlier instrumental, or intentional if seen from a Gallus' point of view, but both of them from within the religious framework. The latter is more of a socio-functional type, giving an individual entry to the group of the Galli.

\subsection{A. B. Cook: to Increase the Fertility of Mother Earth}

Cook agrees with Frazer's interpretation which, however, is based mainly on the Phrygian myth. Cook, instead, wants to focus on the myths of Zeus Sabazios. Clemens of Alexandria (Protr., II, 13-16) relates how Zeus, metamorphised as a bull, made love with his mother Demeter, this enraged her and she could only be entreated by a fraudery. Zeus tore off the testicles of a ram, and flung them into Demeter's lap, thus paying a sham penalty for his lovemaking by pretending that he had castrated himself. Cook interprets this episode as an aitiological myth, indirectly showing that the actors in the cult of Zeus Sabasios offered their virilia, or failing that, the genitals of a ram. Cook then argues that the worshippers sought to increase the fertilising powers of their Goddess by giving her their own fertility (Cook 1914: 390-396). ${ }^{10}$

Cook's hypothesis, in accordance with Frazer, but based on the Zeus Sabazios myth, is a functional explanation. Seen from a Gallus' point of view it can be regarded as intentional.

\subsection{R. Farnell: Assimilation to Cybele}

Farnell suggests that in the ecstatic and emotional festival a Gallus in various ways sought communion with the Goddess. He could be called, according to Photius, $x u ́ \beta \eta \beta O \varsigma$, and changed his dress after the castration to female clothing. The ritual of self-mutilation may have arisen from ecstatic necessity to assimilate oneself to the Goddess and by this charge oneself with her power (Farnell 1907: 300-302).

Farnell's hypothesis is a functional explanation that enables an individual to assimilate to the Goddess.

\subsection{A. D. Nock: a Means to Guarantee Permanent Cultic Purity}

Nock discusses Cook's and Farnell's interpretations, he accepts the earlier and repudiates the latter, but proposes another explanation of the custom,

\footnotetext{
10 See also Vermaseren 1977: 105 concerning this mythological tradition and the Taurobolium.
} 
which, as he remarks, was anticipated but not developed by Hepding (1903: 162). Nock starts from the fact that many sacred functions could only be performed by those qualified by permanent or temporal continence. Nock then argues that the self-castration brought about a permanent cultic purity, in order that a Gallus may be perfectly fitted to serve the Goddess throughout his whole life. He is castus after the castration (Isidore, Orig. X, 33); árvós (Anth. Pal. VI, 220, 3). Nock then argues that the eunuchs could be compared to the virgin and the child in various cults demanding cultic purity and points to Eugen Fehrle's investigation (Fehrle 1910) into how the pure maiden and child promoted fertility in the fields and in marriage. Nock emphasizes that the requirement of chastity was based on the abstaining from polluting sexual intercourse, by analogy abstention from special kinds of food and drink etc., not from a positive value of the abstention (Nock 1972: 27-33).

\subsection{Walter Burkert: a Socio-functional Hypothesis of the Survival Value of Self-castration}

Walter Burkert wages war against the earlier interpretations and declares that "modern explanation in terms of 'belief' are guesswork" with references to Cook - and then indirectly to Frazer - and also to Farnell and Nock. Burkert wants instead to put forward a sociological explanation. The cultic self-castration, following an established pattern, but performed in a state of mind when the man could not give reasons for his behaviour, is an act that made the initiand take leave of ordinary society. Apostasy is impossible and he is irrevocably an adherent to his goddess. Burkert also concludes that because he is neither male nor female, his life could be spared in periods of wars, when a conqueror killed all the adult men and abducted the women, leaving the eunuch, as is shown in Euripides Orestes (1527 f.), where a eunuch is saved for this reason.

Burkert also conjectures that the sanctuaries presided over by eunuchs could have been the only social organizations that survived the really dark ages in Anatolia before the Persian rule. This may explain why, in the "holy city" of Hierapolis or Metropolis, we find the Anatolian Goddess (Burkert 1979: 105).

It is my opinion that Burkert's socio-functional hypothesis is guess work of a higher degree than those of his aforementioned collegues. His evidence for the survival value of eunuchism during the dark ages in Anatolia, a literary passage in Euripides, seems rather strained and of ad hoc character. Moreover, I cannot see why a Gallus should not be able to 
give reasons for his behaviour. Is Burkert hinting at a psychodynamic understanding? Another reading of Burkert could be that he is carrying on a sociological hermeneutic of suspicion that exposes what he deems to be the real function of the ritual, its survival value. But to my mind this is to postulate, on scanty evidence, an extreme, and I must add, incredible, functionalism.

It may be of more interest to note that Burkert delineates a diffusion of traditions from the Semitic Tammuz and Sumerian Dumuzi and the latter's role in the myth of Inannna's descent to the Underworld. Especially the wedding passage in the Phrygian myth, when Agdistis interrupts the wedding and drives Attis crazy, is compared by Burkert with Inanna's ascension from the Underworld in the company of the Gallu demons. She lets the Gallu demons seize Dumuzi and bring him to the Netherworld, because she finds that her husband has not lamented her, even though she was imprisoned in the Underworld. Burkert conjectures that these Gallu demons could in some way be connected with the Galli of Cybele (Burkert 1979: 110-111). ${ }^{11}$

This conjectural hypothesis, could be placed alongside yet another element from the assumed Mesopotamian tradition. In order that the imprisoned Inanna would be able to ascend from the Underworld, father Enki, the god of wisdom, cut dirt from under his fingernails and from it made a kurgarra and a galatur, creatures neither male nor female, that sprinkled the water of life and gave Inanna the bread of life so she could ascend (Wolkstein and Kramer 1984: 64-67). It is also tempting to compare this mythologem with the names Digiti Idaei and Idaei dactyli of the Galli (see part 2.1).

\subsection{Näsström's Functionalistic Interpretation of the Galli as Liminal Personae}

According to Näsström, we find the clue to the explanation of the inner life of Attis, as portrayed in Catullus' famous poem about him (LXIII), and then also of the castration of the Galli, in the indefinite and vague position of the main character embodying the liminal phase in a "Rite de Passage". Näsström (1989: 92) writes that;

the castration of the Attispriests was not depending on frenzy sent by the divine ont of the blue, but on a human conception to establish a position at the limit

11 It is impossible from considerations of space to discuss this very complicated diffusion of traditions in detail. See Burkert 1979: 99-122 with bibliographies. 
of the divine and the mortal above the conditions of mankind. The way to salvation for those was the utter abhorrence of love.

Näsström based her fruitful interpretation on van Gennep's classification of "Rites de Passage", especially the liminal phase, which have been modified by Victor Turner to include what he calls liminal personae, i.e. those upholding a more or less permanent liminality (Turner 1969). Näsström used this extension of the liminal to account for the fact that the "Attis priests" in their abhorrence of love castrated themselves; by this act they are also irreversibly set outside ordinary human nature. They are established, according to Näsström's interpretation, as transcendental existences, neither gods nor men, but intermediaries like Attis between the human world, characterised by Eros and Thanatos, and the other world, wherein we meet immortality and procreation of a non human kind. The Galli repudiate human love and procreation and have thus attained a position beyond death. They are "betwixt and between", to use the language of the late Victor Turner (Näsström 1989: 78-84).

In my opinion Näsström's structuralistic interpretation is a good example of how we can use modern interpretative tools on religious material from Graeco-Roman Antiquity. Reading Näsström enables us to get a sort of existential understanding of what a Gallus could have thought about his intermediary position between this world and the realm of the Gods. ${ }^{12}$ But if we take a closer look at Turner's category of liminal personae, it becomes more puzzling, because it tends to include all human beings that professionally, and more or less permanently, deal with the divine, i.e. stand at the threshold between the sacred and the profane. All of these can also be seen to have an intermediary role by their association with the sacred. It seems that Näsström has acknowledged this dilemma, for she writes (Näsström 1989: 80):

There must have been specific motivations for this ritual performance which implicated a mediating position, but these incitements where hidden for the contemporary authors as well as it is hidden for modern research.

The ritual act is deemed to be too devastating only to be explained by the receiving of an intermediary threshold position in analogy to Attis' own mythological role (Näsström 1989: 80).

\footnotetext{
12 Compare Weigert-Vowinkel's interpretation "The believer who experiences his own subservience to the sexual instincts, demands that the priest, the intermediary between God and man, live independent of instinctual life, as an example for him" (WeigertVowinkel 1938: 374).
} 


\subsection{Weigert-Vowinkel: a Psychological Interpretation of Self-castration as a Regressive Solution of the Oedipus Complex}

The placing together of religion, sexuality and self-aggression that we associate with psychotic behaviour connotates for many the interpretations given by Sigmund Freud. According to him the human being always has to cope with three categories of suffering. Our culture checks the sexual impulse, we are threatened by the overpowering forces of Nature, and other human beings cause us suffering. But by regression to a child's horizon of understanding, with our almighty parents projected upon the whole of the Cosmos and seeking compensation for a lost world wherein the Gods - the parents - were punishing and rewarding, the human being finds illusionary help (Cullberg 1985: 74-79).

Edith Weigert-Vowinkel connects this approach to the religious mind with Freud's well known exegesis of the Oedipus myth. ${ }^{13}$ The self-castration of the Galli is, accordingly, a means for a Gallus to be able to adore the Great Mother - the symbolic representation of his own biological mother - without being threatened by his own genital sexuality, which challenges the father. The Galli's adoration of Cybele is a compensation and a regression to the undisturbed relation between a mother and a son, and the castration secures for ever this religious illusion, because no genital sexuality is threatening. Weigert-Vowinkel writes (1938: 372):

Thus the follower of Attis, in the thralls of the Great Mother, renounces his own individuality, he returns to the lap of the mother, who is reconciled by his self-punishment, he returns to a plant-like feminine-childish dependence on her. As the castrated youth, he resembles the feminine deity; in his conversion into a tree, he is the symbolic penis of mother earth, which draws its strength from her alone. The surviving Cybele worshipper withdrew from the masculine rivalry. From that time on, he led the childishly protected life of the Metragyrtes, the begging monks.

Weigert-Vowinkel considers the Phrygian myth of Attis as a projection and dramatization of the Oedipus complex among boys that have grown up in a matriarchal milieu. She bases her theories on Albrecht Dieterich's and J. J. Bachofen's theories of matriarchal dominance in the early history of Asia Minor (Weigert-Vowinkel 1938: 349). But Weigert-Vowinkel also correlates this historiographical hypothesis with her clinical experience as a psychiatrist of maladjusted boys that have grown up in families with an absent father and an overpowering mother. The mother has then been

\footnotetext{
13 See also the psychodynamic studies by Leuba (1968), Meslin (1974) and Pasche (1975).
} 
both the allower and the forbidder and all the ambivalence of the infantile emotional life, i.e. the Oedipus complex, has been directed at the mighty mother and there has been no other outlet for the young man's aggressive and destructive tendencies. He remained bound up in infantile fixation on the mother (Weigert-Vowinkel 1938: 368-373).

It would be easy to dismiss this Interpretatio Freudiana as a way of translating obscurities from classical Antiquity by modern Freudian mythology - obscurum per obscurius! However, we will temporarily keep this interpretation on the scene and begin by criticising parts of it and then compare it with two modern, possibly analogous, examples.

The vehemently debated hypothesis of a stage of matriarchy in the early history of Asia Minor and elsewhere has been discarded by the modern anthropological and historical sciences (Fluehr-Lobban 1979; Binford 1981-82).

The next issue, the scientific value and universality of the Oedipus complex, has also been a popular battle-ground, which in its turn is connected with how we esteem the psychoanalytical movement. This is extremely thorny terrain and I find it impossible in this context to give some sort of overview. I will, however argue, leaning upon the psychoanalytically inspired anthropologist Melford E. Spiro, who argues in Oedipus in the Trobriands that there are deep motivational structures underlying human behaviour, especially concerning sexuality and aggression, that are best studied from a psychoanalytical perspective with due attention paid to the formative influence of social structures and belief systems. Spiro argues that the best available coherent corpus of theory linking the panhuman structure of the family to concepts of individual motivation and concepts of social organisation and culture is psychoanalysis. His point of departure is that no matter how much societies may differ, they must all cope with man's prolonged infantile dependency, whose determining psychodynamic constants shape the individual. He writes:

Since religion (because, perhaps, of its frequent use of family idioms) like politics (for the same reason) is an especially important cultural domain for the expression of repressed Oedipal conflicts, it might be added that other differences between societies in which the Oedipus complex is repressed in contrast to those in which it is extinguished may also be seen in such diverse religious phenomena as ritual circumcision and clitoridectomy, ascetic abstinences and self-torture, sexualized goddesses and witches, celibate priests and priestesses, mystical trance states and many others. (Spiro 1987: 97)

Spiro argues, contrary to Malinowski, that the Oedipus complex is universal but not transculturally uniform. Its structure, the Oedipal triangle 
with its objects for sexual and aggressive wishes, is the most stable part, almost everywhere consisting of a mother or a substitute for a mother and a father or a substitute for a father, and constituting a group inhabiting a common household which sustain certain modes of social relationships with each other. The other parts, what Spiro labels the Oedipus complex's intensity and outcome, are according to the ethnographical evidence crossculturally variable. The outcome of the whole Oedipus complex may variously take the form of extinction, repression or incomplete repression (Spiro 1987: 87-92).

Spiro then remarks that he has missed an analysis of the role of the Oedipus complex in anthropological interpretations of the often painful and brutal initiation rituals aimed (here not commenting on other meanings that he also acknowledges) at the removal of the Oedipal wishes of sons by, inter alia, physical torture, ordeals and phallic mutilations in the form of circumcision, subincision and superincision (Spiro 1987: 93-97).

The question now arises of whether we can consider the self-castration of Cybele's Galli, which functions as a transitional ritual, as a regressive, or even failed, solution to the Oedipus complex, even though its matriarchal basis is in Weigert-Vowinkel's theory shattered. An intriguing situation develops, because Malinowski - Spiro's opponent in the question of the universality of the Oedipus complex - argues that because the Trobriand society is matrilineal ${ }^{14}$ and lacks an authoritarian father, it does not produce an Oedipus complex! This is, as we have seen, in total opposition to Weigert-Vowinkel, who starts with a matriarchal background, which is used to explain that the Mother Goddess is both nurturing and destructive and that this situation causes a heightening of the Oedipal drama with destructive consequences.

We will now try, as an experiment, to base our interpretation of the behaviour of the Galli upon Spiro's hypothesis of the universality of the Oedipus complex and the supposed connection with violent initiation rituals. That is, we will see if it is possible by a modification of Weigert-Vowinkel's hypothesis to further the explanation of the Galli's self-castration. But this tentative interpretation will first be compared with two modern and, maybe, in some way analogous studies. Both of them are to some extent working with psychoanalytic hermeneutics.

14 Also disputed by Spiro (1987: 72). 


\subsection{The Hijras of India - neither Man nor Woman}

Serena Nanda's anthropological study provides us with a picture of the enigmatic Hijras of India, a religious community of castrated men who dress and act like women and worship Bahuchara Mata, one of the many versions of the Indian Mother Goddess. By a ritualized emasculation operation, often conceptualized in Hijra's own thinking as self-castration, a male individual is made a member of the community and linked to two of the most powerful figures in the Hindu religion, Shiva - who incorporates both male and female characteristics - and the Mother Goddess. The Hijras points to Arjun, one of the heroes of Mahabharata and also identified with Shiva, as a mythological model. Arjun, who is forced to be incognito for a year, braided his hair, wore female dress and hid as a eunuch serving the ladies at the court. Arjun also participated at weddings and births (Nanda 1990: XV, 24-38).

Nanda is of the opinion that the Hijras' claim of religious power rests on their renunciation of male sexuality and their identification with other religious ascetics in Indian society. They make their living by giving performances at weddings, blessing the newly married couple for fertility by dances and songs that show an aggressive display of imitated female sexuality (Nanda 1990: 1-5). She writes:

It would seem to be a paradox that the hijras, impotent and emasculated men, have this traditional role of conferring blessings of fertility on newborn males and on newly weds. But the hijras are not merely ordinary, impotent men. As ritual performers, they are viewed as vehicles of the divine power of the Mother Goddess, which transforms their impotence into power of generativity. It is this power, which is displayed in the shameless, aggressive feminine sexuality of the hijras' performances that legitimates, even demands on such occasion, their presence. (Nanda 1990: 5)

Nanda also uses Sudhir Kakar's psychoanalytic study of Hinduism, family and personality in India (Kakar 1981), and she asks how the forces that motivate castration may be understood and related to the cultural context. Kakar emphasizes that the Mother Goddess in Hindu mythology has both beneficent and destructive traits, which represent an ambivalence towards the real mother. The traditional village ceremony in which men dress as women, the transvestite customs of low-caste beggars in Bellary and transgenderism in Hindu mythology points for Kakar not to an extreme manifestation of marginal behaviour, but that these groups disclose governing emotional constellations in the Hindu society, i.e. the Oedipus complex (Kakar 1981: 102). 
Nanda transposes this understanding to the Hijras. The castration ritual is seen as a way both of fleeing the demanding and arousing mother and of being reconciled with her. The Hijras say: It is the Mata who gives us life, we live only in her power. A Hijra identifies with the mother, remarks Nanda, thereby reducing his anxiety over separation from her. Nanda also points out that the Hijras encourage men with unclear gender identity to join their communities, and so to give up their useless male organs for a ritual role of givers of generativity. The ritual can also be interpreted, as she tries to show, as a way of resolving, by a cultural pattern, the Oedipal conflict. But it can furthermore be seen as a means of warding off death, by their identification with the life-giving mother goddess. Nanda rounds up the subject by calling attention to the fact that the psychological motivations are reinforced by material concerns, the Hijras live by their ritual performances and emasculation protects their economic niche from faked uncastrated men pretending to be Hijras (Nanda 1990: 36-37).

\subsection{Modern Self-mutilative Behaviour and Beliefs}

Armando R. and Barbara Favazza's monograph Bodies under Siege. Selfmutilation in Culture and Psychiatry is a study that from the perspective of cultural psychiatry, lists all sorts of self-mutilative behaviour in both past and contemporary societies. They make an overview of mutilative beliefs, culturally sanctioned and clinical cases of mutilation of the body parts - the head, limbs, skin and genitals - and end the monograph with therapeutical suggestions. What is of interest here, for the study of Cybele's Galli, is that Favazza and Favazza list some modern case studies of self-castration where religious beliefs have played a significant part. Especially Matthew 19:12 and there be eunuchs who have made themselves eunuchs for the Kingdom of Heaven's sake have been used by individuals in case-studies as an aition for their self-mutilative behaviour. Favazza and Favazza also mention Blacker and Wong's study of four psychotic or border-line men. Blacker and Wong found six common characteristics in these cases. (1) A deprived childhood with a dominant mother and an absent father. (2) The self-castration was a culmination of a long sexual gender confusion. (3) Their relationship with women was submissive and masochistic and, according to Blacker and Wong, indicated a desire for an infantile relationship with a mother figure that would not be threatened by genital sexuality. (4) The act served to relieve depression and could "be considered an attenuated suicide, a compromise that averted total 
annihilation.". (5) A strong female identification. (6) Repudiation of the male organs (Blacker and Wong 1963: 169-176).

Favazza and Favazza's conclusions concerning genital self-mutilation, on the basis of several other case studies, are that socially deviant male selfmutilators tend to be psychotic at the time of the act and the motives provided by the patients were in the descending order: the wish to be or delusion of being female; thoughts about homosexuality, relief of psychical pain, guilt over sexual urges such as incest; religiosity; command hallucinations; punishment for failures in the male role. Non-psychotic selfmutilators are most likely men with character disorders or transsexuals that have wished to become female (Favazza and Favazza 1987: 187).

\section{A Tentative Evaluation of the Proposed Explanations}

How are we now to choose between and to evaluate the various explanations and parallels that have been put forward? I want first to vindicate a plurality of explanations, in spite of Walter Burkert's vehement repudiation of Cook, and indirectly Frazer, Farnell and Nock. Because the plurality has grown out of different types of questions and theoretical views. Burkert is partly working genetically with the Mesopotamian background, partly giving a sociological and functional interpretation. Frazer can be said to explain by definition, or genetically, when he points to the super-paradigm of dying and rising vegetation deities. But he offers an intrinsic religious understanding, intentional from a Gallus point of view, when he argues that self-castration regenerates the vegetational cycle. That intrinsic understanding applies also to Cook and Farnell. Nock emphazises a ritual function leading to ritual purity. Näsström interprets structuralistically in the light of Victor Turner's modification of van Gennep's liminal phase in a transitional ritual. Weigert-Vowinkel offers a psycho-analytical explanation that explains by reference to the ultimate causative Oedipus complex. The self-castration of Cybele's Galli is a much too complicated phenomenon in the history of religions, and can be viewed from so many angles as we have seen, to be mono-theoretically treated. Therefore it seems to me impossible to reduce the phenomenon under scrutiny to one single cause that determines the whole complex.

I will instead build my interpretation on an application of Spiro's model of the interaction of personality and social systems in the performance of a social role. Before the days of Culture and Personality studies it was 
thought, according to Spiro, that this or that social act was performed because it was a part of the cultural heritage. This is partly true, but pointing to the cultural heritage does not explain how and why a person chooses a special social role. This must be interpreted by the process of inheriting by learning. Either by the social sanction theory, that is that a person learns through positive and negative sanctions the norms and social roles of a given society. Or a person chooses to follow a norm or a special social role because it satisfies personal needs and it is provided by society. Spiro argues that social systems operate by means of personality and personality functions by means of social roles, an interaction of society and personality. That is, although social roles are prescribed by the cultural heritage, their performance is motivated by the expectation of satisfying personal needs (Spiro 1987: 109-128). I will now try to show how this can be applied to the Galli, see the heuristic model for the explanation of Galli's self-castration on the next page.

The intention of this model of how an individual may have acquired the social role of being a Gallus is to show, on the basis of the analysed hypotheses, the possible interaction of various factors, working on different ontological and epistemological levels. The general and culturally known motive for the act was of course the imitation of Attis - Imitatio Attidis - here interpreted as a general motive, because, even if it seems that the Phrygian version of the Attis' myth in fact functioned as the Galli's intrinsic religious motive for the act, there are other mythological variants, as we have seen.

The manifest and culturally intrinsic functions of the role performance, motivated by the Imitatio Attidis, would then have been, e.g., according to Frazer, to regenerate the vegetational cycle. (See the functions postulated by the historians of religion, Frazer, $(\mathrm{Cook})^{15}$, Farnell and Nock, all of whom seem to be satisfied with an intrinsic religious explanation.) To my mind, these explanations could be labelled non-reductive, sui generis. All of them seem to have some support in the literary evidence, even though Frazer's grandiose paradigm has been severely pruned. They can, as the general motive, be seen as necessary but not as sufficient to explain the self-castration of the Galli.

The conscious and culturally intrinsic general motive and the aforementioned functions are, I want to argue, inadequate, in themselves, to explain such a drastic and violent religious role performance. We have seen

\footnotetext{
15 Note that the Zeus Sabazios myth is used by Cook, so that even though he agrees with Frazer's interpretation, it is unclear if he counts on an Imitatio Attidis-motive.
} 


\section{A heuristic model for the explanation of Galli's self-castration}

\section{Conscious and culturally intrinsic motives}

In general: Imitatio Attidis

Unconscious and culturally extrinsic motives

The need to solve the Qedipal complex
Manifest and culturally intrinsic functions

Frazer: To generate the vegetational cycle

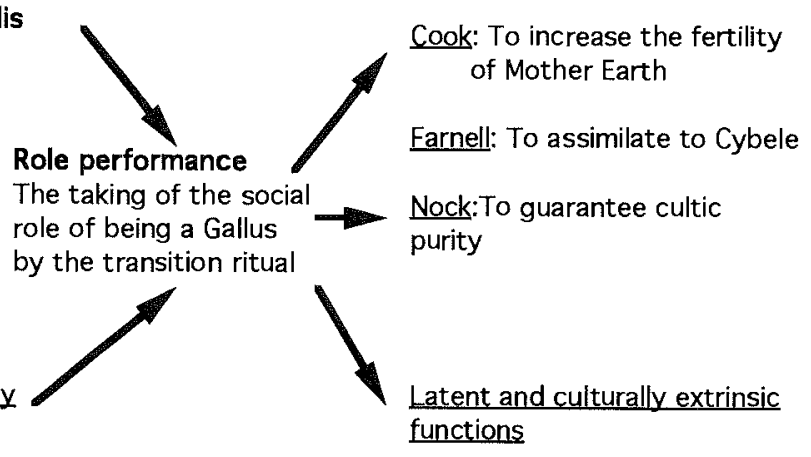

Structural function

Näsström: To function as liminal personae

\section{Sociological function}

(Burkert: To survive in a belligerent society)

Psvcho-analytical function Weigert-Vowinkel: To solve the Oedipus complex by a regressive solution

\section{Comparative}

Material

1. The Hijras (Nanda)

2. Modern cases of selfemasculation (Favazza Favazza) 
that Weigert-Vowinkel inter alia suggests an unconscious and culturally extrinsic motive; the need to solve the Oedipal complex. But before we plunge into the more or less mythological depths of psycho-analysis, I want to try to evaluate the explanative force of Burkert's and Näsström's hypotheses.

In my opinion it is adequate and necessary to try to apply a sociological interpretation of the recruitment of the Galli. Tentatively, perhaps, an analogue to the Indian perspective of the Hijras could be in place. The Galli earned their living by public performances, telling fortunes, begging, etc., occupying exactly the same economic niche as the Hijras. This could, I conjecture, be one of the non-religious motives for joining the Galli. Compared to this Burkert's survivalist explanation seems to be more of an ad-hoc character.

The explanative value of Näsström's structuralist explanation is hard to estimate. She establishes an intermediate position for the Galli, just as Attis has this role in the mythology, but this is, in my opinion, not an explanation for their behaviour in a strict sense, but a way of understanding how they could have thought about their existential position. And this is a function of the role performance which is latent and culturally extrinsic if we take leave of an understanding of the intermediate position as a realised example of Imitatio Attidis, and instead operate with liminal personae.

A psycho-analytical explanation which pays due attention to the formative role of religious traditions could be outlined as follows:

The traditional behaviour of the Gallus is seen as a culturally established role which offers the individual a culturally sanctioned solution to the Oedipal conflict. The performance of the role of a Gallus enabled an individual to solve his unconscious and culturally extrinsic personal need - solving the Oedipal complex - and by that he also furthered manifest and culturally intrinsic functions. This very tentative explanation can be supported by the fact that a phenomenological parallel, the castration of the Hijras, is explained in the same way by the anthropologist Seren a Nanda. She also noted that Weigert-Vowinkel's study is very close to her own interpretation of the Hijras (Nanda 1990: 147 note 8; compare also the Indian material in Gray 1912).

Nanda explicitly describes the various conscious and culturally intrinsic motives for, and functions of, the Hijras, by giving prominence to their assimilation to Bahuchara Mata as the source of their generative potency. She emphasizes that emasculation is sometimes thought of as self-castration and that it guarantees their cultic purity as real Hijras. 
Nanda even proposes a psycho-analytical understanding which is based on the unconscious and culturally extrinsic Oedipus complex.

The psychiatrists Favazza and Favazza also work with a psychodynamic understanding, but then out of modern case-studies of self-castration. It is of special interest here that they have noticed how Matthew 19:12 and other passages have served the purpose of giving a cognitive frame for an act that otherwise would have been totally inexplicable.

It seems that a modification of Weigert-Vowinkel's theory - without postulating a matriarchal period in the early history of Asia Minor could be supported by Spiro, concerning the catholicity of the Oedipal complex, and by the modern analogous material surveyed by Nanda and Favazza and Favazza. It is also possible to connect this explanation with the outlined manifest and culturally intrinsic functions. The selfcastration of the Galli could be seen as an interaction between an intrinsic religious tradition that enables a socially sanctioned role performance, that solves the emotional problem of the Oedipal conflict in a regressive and brutal way.

That is, in sum, the strength and weakness of a psycho-analytical explanation, because it can be united with all other interpretations; it even survives an amputation of its postulated matriarchal basis, and it would probably blunt the razor of Ockham! We may in this context notice that it lacks tangible evidence concerning the family situation for those individuals that volunteered to become Galli, and it is only supported by modern analogous material.

How we evaluate a psycho-analytical explanation of the self-castration of the Galli depends on our general opinion of the explanative and heuristic value of psycho-analysis - a question that can not be solved in this article.

I will end by reminding the readers that it is not only our contemporary time, with all sorts of body-histories (Brown 1988; McGuire 1990), that has been interested in how the human body mirrors societal and religious concepts. In London, in the year 1653, a work of M.D. chirosophus John Bulwer was printed with a title that I do not want to withdraw from your notice; "Anthropometamorphosis: Man transform'd: Or, the Artificiall CHANGLING Historically presented, in the mad and cruel Gallantry, folish bravery, ridiculous Beauty, filthy finenesse, and loathsome Loveliness of most Nations, fashioning and altering their bodies from the mould intended by NATURE". Bulwer writes about the Galli, following the vegetational interpretations made by the Church Fathers, but in passing making "A Modest Apology" for the subject, but exculpating himself by the fact that he would otherwise have to "answer it to Nature". 


\section{References Cited}

Augustine

1957 The City of God against the Pagans; vol. 1. Books I-III. Transl. by George E. McCracken, Cambridge, MA: Harvard University Press. (Loeb Classical Library, 411)

Arnobius of Sicca

1949 The Case against the Pagans; 2 vols. Transl. by George E. McCracken. Westminster, ML: Newman Press. (Ancient Christian Writers, 7-8)

Benveniste, $\mathbf{E}$.

1938-39 La Légende de Kombabos, In: Mélanges syriens offerts à Monsieur René Dussaud; vol. 1: 249-258. Paris: Libraire orientaliste Paul Geuthner. (Syrie. Service des antiquités et des beaux-arts. Bỉbliothèque archèologique et historique, 30)

Bilde, Per

1990 Atargatis/Dea Syria: Hellenization of her Cult in the Hellenistic-Roman Period? In: Religion and Religious Practice in the Seleucid Kingdom; pp. 151-187. Aarhus: Aarhus University Press (Studies in Hellenistic Civilisation, 1)

Binford, Sally

1981-82 Myths and Matriarchies. Anthropology 1981-82/1: 150-153.

Blacker, K. H., and N. Wong

1963 Four Cases of Autocastration. Archives of General Psychiatry 8: 169-176.

Browe, P.

1936 Zur Geschichte der Entmannung. Eine religions- und rechtsgeschichtliche Studie. Breslau: Müller \& Seiffert. (Breslauer Studien zur historischen Theologie, N.F., 1)

Brown, Peter

1988 The Body and Society. Men, Women and Sexual Renunciation in Early Christianity. New York: Columbia University Press.

Burkert, Walter

1979 Structure and History in Greek Mythology and Ritual. Berkeley: University of California Press.

Cook, Arthur Bernard

1914 Zeus. A Study in Ancient Religion; vol. 1: Zeus God of the Bright Sky. Cambridge: Cambridge University Press.

Cullberg, Johan

1985 Dynamisk psykiatri i teori och praktik. Stockholm: Natur och Kultur.

Farnell, L. $\mathbb{R}$.

1907 The Cults of Greek States 1. Oxford: Clarendon Press.

Favazza, Armando $\mathbb{R}$. , and Barbara Favazza

1987 Bodies under Siege. Self-mutilation in Culture and Psychiatry. Baltimore: John Hopkins University Press.

Fehrle, $\mathbf{E}$.

1910 Die kultische Keuschheit im Altertum. Giessen: A. Töpelmann Verlag. (Religionsgeschichtliche Versuche und Vorarbeiten, 6)

\section{Firmicus Maternus}

1970 The Error of Pagan Religions. Transl. by C. A. Forbes. Westminster, ML: Newman Press. (Ancient Christian Writers, 37) 
Fluehr-Lobban, Carolyn

1979 A Marxist Reappraisal of the Matriarchate. Current Anthropology 20: 341-360.

Frazer, James George

1914 The Golden Bough. A Study of Magic and Religion; vol. 4/1: Attis, Adonis, Osiris. Studies in the History of Oriental Religion 1. In: James George Frazer, [3. ed.] London: MacMillan and Co.

Graillot, H.

1912 Le culte de Cybele. Mère des Dieux à Rome et dans L'Empire Romain. Paris: Fontemoíng et Companíe. (Bibliothèque des Écoles françaises d'Atènes et de Rome, 107)

Gray, Louis $\mathbf{H}$.

1912 Eunuch. In: Encyclopedia of Religions and Ethics; vol. 5; pp. 579-584. Edinburgh: T.\& T. Clarke.

Gurney, O. R.

1962 Tammuz Reconsidered: Some Recent Developments. Journal of Semitic Studies 7: 147-160.

\section{Hackett-Fischer, David}

1970 Historians' Fallacies. Toward a Logic of Historical Thought. New York: Harper \& Row.

Harré, R., and P. F. Secord

1972 The Explanation of Social Behaviour. Oxford: Basil Blackwell.

\section{Hepding, Hugo}

1903 Attis, seine Mythen und sein Kult. Gieszen: J. Ricker'sche Verlagsbuchhandlung. (Religionsgeschichtliche Versuche und Vorarbeiten, 1)

Kakar, Sudhir

1981 The Inner World. A Psycho-analytical Study of Childhood and Society in India. Delhi: Oxford University Press.

Leuba, J.

1968 Mère phallique et mère castratrice. Revue Français de psychoanalyse 12: 287296.

\section{Lucianus}

1976 The Syrian Goddess (De Dea Syria), Attributed to Lucian. Transl. and comm. by Harold W. Attridge and Robert A. Oden. Missoula, MT: Scholars Press.

McGuire, Meredith $\mathbf{B}$.

1990 Religion and the Body: Rematerializing the Human Body in the Social Sciences of Religion. Journal for the Scientific Study of Religion 29: 283-296.

Meslin, M.

1974 Réalités psychiques et valeurs religieuses dans les cultes orientaux. ( $\mathrm{I}^{e r}-\mathrm{IV}^{e}$ siècles). Revue Historique 512: 289-314.

Nanda, Serena

1989 Neither Man nor Woman: The Hijras of India. Belmont, CA: Wadsworth Publishing Company.

Näsström, Britt-Mari

1989 The Abhorrence of Love. Studies in Rituals and Mystic Aspects in Catullus' Poem of Attis. Stockholm: Almqvist \& Wiksell International. (Acta Universitatis Upsaliensis. Uppsala Women's Studies. A. Women in Religion, 3) 
Nock, Arthur Darby

1972 Eunuchs in Ancient Religion. In: Zeph Stewart (ed.), Arthur Darby Nock. Essays on Religion and the Ancient World; vol. 1: 7-15. Oxford: Clarendon Press. [Earlier publ. 1925 in Archive für Religionswissenschaft 23: 25-33].

Pasche, F.

1975 Le complexe d'Agdistis. Revue Français de Psychoanalyse 39: 990-991.

Podemann Sørensen, Jørgen

1989 The Myth of Attis. Structure and Mysteriosophy. In: Jørgen Podemann Sørensen (ed.), Rethinking Religion. Studies in the Hellenistic Process; pp. 23-29. København: Museum Tusculanum Press. (Opuscula Graecolatina, 30)

Prudentius

1961 Prudentius; vol. 2: Peristephanon liber; pp. 98-345. Transl. by H. J. Thomson. Cambridge, MA: Harvard University Press. (Loeb Classical Library, 398)

Sanders, G. M.

1972 Gallos. In: Reallexikon für Antike und Christentum; Bd 8; pp. 984-1034. Stuttgart: Anton Hiersmann.

Spiro, Melford $\mathbb{E}$.

1987 Culture and Human Nature. In: Benjamin Kilborne and L. L. Langness (eds.), Culture and Human Nature. Theoretical Papers of Melford E. Spiro; pp. 72106. Chicago: University of Chicago Press.

Thomas, Garth

1984 Magna Mater and Attis. In: Aufstieg und Niedergang der Römischen Welt; II; Bd. 17/3; pp. 1500-1535. Berlin: Walther de Gruyter.

Turner, Victor W.

1969 The Ritual Process. Struct ure and Anti-structure. London: Routledge \& Kegan Paul.

Vermaseren, M. J.

1966 The Legend of Attis in Greek and Roman Art. Leiden: E. J. Brill. (Études Préliminaires aux Religions Orientales dans L'Empire Romain, 9)

1977 Cybele and Attis. The Myth and the Cult. London: Thames and Hudson.

Widengren, Geo

1953 Quelques remarques sur l'émasculation rituelle chez peuples semitiques. In: Studia Orientalia Ioanni Pedersen; pp. 337-384. Copenhagen: Einar Munksgaard.

Weigert-Vowinkel, Edith

1938 The Cult and Mythology of the Magna Mater from the Standpoint of Psychoanalysis. Psychiatry. Journal of the Biology and Pathology of Interpersonal Relations 1: $347-378$.

Wolkstein, Diane, and Samuel Noah Kramer

1984 Inanna. Queen of Heaven and Earth. London: Rider \& Company. 